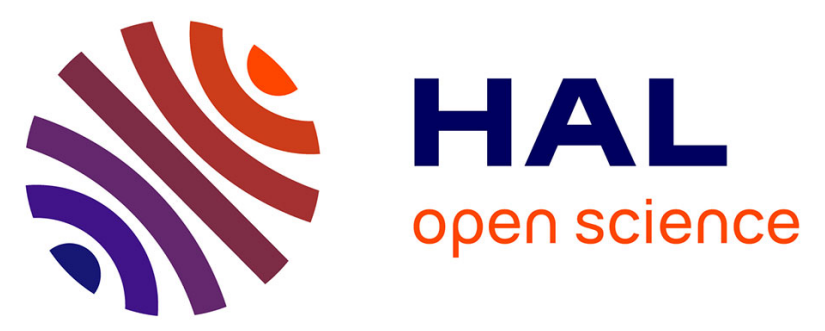

\title{
Comparison of Pre- and Post-Operative Characteristics in Octogenarians Having Isolated Surgical Aortic Valve Replacement Before versus After Introduction of Transcatheter Aortic Valve Implantation
}

Moukda Khounlaboud, Erwan Donal, Vincent Auffret, Amedeo Anselmi, Anne Ingels, Erwan Flécher, Jean-Philippe Verhoye, Claude Daubert, Hervé Le Breton, Philippe Mabo, et al.

\section{- To cite this version:}

Moukda Khounlaboud, Erwan Donal, Vincent Auffret, Amedeo Anselmi, Anne Ingels, et al.. Comparison of Pre- and Post-Operative Characteristics in Octogenarians Having Isolated Surgical Aortic Valve Replacement Before versus After Introduction of Transcatheter Aortic Valve Implantation. American Journal of Cardiology, 2015, 116 (6), pp.933-937. 10.1016/j.amjcard.2015.06.019 . inserm-01172716

\author{
HAL Id: inserm-01172716 \\ https://www.hal.inserm.fr/inserm-01172716
}

Submitted on 7 Jul 2015

HAL is a multi-disciplinary open access archive for the deposit and dissemination of scientific research documents, whether they are published or not. The documents may come from teaching and research institutions in France or abroad, or from public or private research centers.
L'archive ouverte pluridisciplinaire HAL, est destinée au dépôt et à la diffusion de documents scientifiques de niveau recherche, publiés ou non, émanant des établissements d'enseignement et de recherche français ou étrangers, des laboratoires publics ou privés. 
Comparison of Pre- and Post-Operative Characteristics in Octogenarians Having

Isolated Surgical Aortic Valve Replacement Before versus After Introduction of

Transcatheter Aortic Valve Implantation

\section{Running title: aortic valve replacement in octogenerians}

Moukda Khounlaboud, MD ${ }^{\mathrm{a}, \mathrm{b}, \mathrm{c}, 1}$ Erwan Donal, MD, $\mathrm{PhD}^{\mathrm{a}, \mathrm{b}, \mathrm{c}, 1}$ Vincent Auffret, MD ${ }^{\mathrm{a}, \mathrm{b}, \mathrm{c}, 1}$ Amedeo Anselmi, MD ${ }^{\mathrm{b}, \mathrm{c}, \mathrm{d}, 1}$ Anne Ingels, MSc ${ }^{\mathrm{d}, 1}$ Erwan Flécher, MD, PhD ${ }^{\mathrm{b}, \mathrm{c}, \mathrm{d}, 1}$ JeanPhilippe Verhoye, MD, $\mathrm{PhD}^{\mathrm{b}, \mathrm{c}, \mathrm{d}, 1}$ Claude Daubert, $\mathrm{MD}, \mathrm{PhD}^{\mathrm{a}, \mathrm{b}, \mathrm{c}, 1}$ Hervé Le Breton, MD, PhD ${ }^{\mathrm{a}, \mathrm{b}, \mathrm{c}, 1}$ Philippe Mabo, MD ${ }^{\mathrm{a}, \mathrm{b}, \mathrm{c}, 1}$ Alain Leguerrier, $\mathrm{MD}^{\mathrm{b}, \mathrm{c}, \mathrm{d}, 1}$

Authors' affiliations:

${ }^{\text {a }}$ CHU Rennes, Service de cardiologie et maladies vasculaires, 2 rue Henri Guilloux, Rennes, F-35000, France

${ }^{\mathrm{b}}$ INSERM, U1099, 2 avenue du Pr Léon Bernard, CS 34317, Rennes, F-35043, France

${ }^{\mathrm{c}}$ Université de Rennes 1, LTSI, 2 avenue du Pr Léon Bernard, Rennes, F-35000, France

${ }^{\mathrm{d}} \mathrm{CHU}$ Rennes, Service de Chirurgie cardiaque, thoracique et vasculaire, 2 rue Henri Le Guilloux, Rennes, F-35000, France.

${ }^{1}$ This author takes responsibility for all aspects of the reliability and freedom from bias of the data presented and their discussed interpretation.

\section{Corresponding author:}

DONAL Erwan, MD, PhD

Cardiology Department \& CIC-IT 804

Hôpital Pontchaillou - CHU Rennes

2, rue Henri Le Guilloux

35000 Rennes -France

Telephone: +33299282525

Fax: +33299282510

e-mail: erwan.donal@chu-rennes.fr 


\section{Abstract}

Aortic stenosis (AS) is the most frequent heart valve disease. Surgical aortic valve replacement (SAVR) is the reference treatment. Transcatheter aortic valve implantation (TAVI) has emerged as an alternative treatment. New strategies for treating the AS are upcoming. The aim of the study was to assess if the clinical profile of octogenarian patients treated surgically before and after the TAVI program initiation has changed. We retrospectively included consecutive octogenarian patients, who underwent isolated SAVR, between January 2006 and December 2011 in a single high-volume center. We compared preoperative and postoperative characteristics before and after the initiation of TAVI (February 2009). 517 patients were included: 229 in the "before TAVI" group (2006-2008), 288 in the "after TAVI" group (2009-2011). The mean age was 83.2 \pm 2.0 in the "before TAVI" group, $83.5 \pm 2.1$ in the "after TAVI" group $(\mathrm{p}=0.106)$. There were no significant differences in preoperative characteristics: NYHA class $(\mathrm{p}=0.374)$, history of heart failure ( $\mathrm{p}=0.680)$, left ventricular ejection fraction $(59.8 \pm 12.2 \%$ in the "before TAVI" group, $59.9 \pm 11.3 \%$ in the "after TAVI" group, $p=0.922)$, coronary artery disease $(p=0.431)$, chronic pulmonary disease $(p=0.363)$, previous cardiac surgery $(p=0.085)$. The logistic EuroSCORE was $7.78 \pm 4.60 \%$ in the "before TAVI" group and $7.33 \pm 3.96 \%$ in the "after TAVI" group $(p=0.236)$. The operative mortality (30-day) was comparable: $5.2 \%$ in the "before TAVI" group, $6.9 \%$ in the "after TAVI" group $(\mathrm{p}=0.424)$. Thus, with the emergence of TAVI, the number of octogenarian patients operated on, their preoperative characteristics and the operative mortality remained comparable.

Key words: aortic valve stenosis, aortic valve replacement, octogenarian, transcatheter aortic valve implantation 


\section{Introduction}

Aortic stenosis (AS) is the most frequently treated heart valve disease ${ }^{1}$. The prevalence of AS increases with age and it affects around $10 \%$ of octogenarians ${ }^{2-6}$. Surgical aortic valve replacement (SAVR) is the standard treatment with good long-term outcomes ${ }^{7-13}$. An alternative treatment appeared in 2002 with the first transcatheter aortic valve implantation (TAVI) ${ }^{14}$. TAVI is indicated in patients with severe and symptomatic AS who are not suitable for SAVR as assessed by a "heart team" ${ }^{15-17}$, and should be considered in patients with high surgical risk who may still be suitable for surgery ${ }^{8,15,16}$. Little is known about the impact of TAVI on the indications to SAVR in the elderly, and whether it has prompted an evolution in the characteristics of elderly patients who actually receive SAVR. In this study, we compared the preoperative features, peri-operative characteristics and 30-day postoperative outcomes of octogenarian patients who underwent isolated SAVR before and after the initiation of the TAVI program in a single tertiary center.

\section{Methods}

We analyzed data from consecutive patients aged over 80 years, who underwent isolated SAVR (i.e. without concomitant coronary artery bypass or other cardiac procedure), between January $1^{\text {st }}, 2006$ and December $31^{\text {st }}, 2014$. All patients were enrolled within a single tertiary center where the TAVI program started in February 2009.

We distinguished 3 groups: the pre-TAVI group (patients operated between January $1^{\text {st }}, 2006$ and December $31^{\text {st }}, 2008$ ), the post-TAVI 1 group (patients operated between January $1^{\text {st }}, 2009$ and December $31^{\text {st }}, 2011$ ) and the post-TAVI 2 group (patients operated between January $1^{\text {st }}, 2012$ and December $\left.31^{\text {st }}, 2014\right)$.

Treatment strategies for individual patients were decided during weekly meetings of a multidisciplinary "heart valve team" including physicians (cardiologists, anesthesiologists, 
geriatricians...) and surgeons working in the same heart valve clinic ${ }^{18}$. The decision to perform SAVR or TAVI was based on the clinical evaluation by cardiologists, surgeons and geriatricians in charge of the patient and the Logistic EuroSCORE I in accordance with the national recommendations. These conform the latest European and American guidelines ${ }^{15,16}$.

The preoperative characteristics, peri-operative data and postoperative mortality and morbidity were collected prospectively at the time of hospital discharge and entered in a computerized database.

The following preoperative characteristics were compared between the pre-TAVI group and each post-TAVI group: mean age, proportion of very elderly patients (aged more than 85 years), gender, New York Heart Association (NYHA) class, history of acute heart failure, history of atrial fibrillation, history of prior pacemaker implantation and echocardiographic data (left ventricular ejection fraction, mean aortic valve gradient, aortic valve area). Data about baseline comorbidities were also analyzed including coronary artery disease (all patients had a coronary angiography before surgery), cerebrovascular disease, peripheral vascular disease, chronic renal failure (defined as a creatinine clearance $<60$ $\mathrm{mL} / \mathrm{min}$ according to the Cockcroft-Gault equation), chronic pulmonary disease (defined as abnormal pulmonary function tests or chronic use of bronchodilators or inhaled steroids), hypertension, diabetes mellitus, obesity (defined as a body mass index $>30 \mathrm{~kg} / \mathrm{m}^{2}$ ). We used Logistic EuroSCORE I ${ }^{19}$ to calculate the estimated operative risk of mortality.

We assessed for the 3 groups the peri-operative data, including operative priority (salvage for surgery performed immediately, emergency for surgery within 24 hours, urgent for surgery within a few days and elective for planned surgery), the cardiopulmonary bypass and cross-clamp time, and the type of prosthesis used. 
We compared the operative mortality (defined as death within 30 days of surgery) and the incidence of in-hospital postoperative complications (reoperation for bleeding, tamponade, prolonged ventilatory support, renal failure, stroke, blood transfusion, atrial fibrillation and pacemaker implantation) between the pre-TAVI and each post-TAVI group.

Continuous variables were expressed as mean \pm standard deviation (SD) and were compared using the Student t-test. Normality of continuous variables was checked through the Kolmogorov-Smirnov test. Categorical variables were expressed as a percentage and were compared using either the $\chi^{2}$ test or the Fisher exact test. All reported p-values were 2-sided. A p-value $<0.05$ was considered significant. Statistical analyses were performed using SAS version 9.3 (SAS Institute Inc).

\section{Results}

During the study period, 845 consecutive patients were included, 229 were in the preTAVI group, 288 in the post-TAVI 1 group and 328 in the post-TAVI 2 group (figure 1). Over time, there was a trend towards an increase in the yearly rate of SAVR performed (figure 1). Similarly, there was an increase in the number of TAVI procedures among octogenarians, 72 cases between 2009 and 2011 and 202 cases between 2012 and 2014 .

Preoperative characteristics were comparable between the pre-TAVI group and the post-TAVI 1 group (table 1). Nonetheless, the post-TAVI 2 group was characterized by less females, lower prevalence of heart failure, of coronary artery disease, of severe left ventricular systolic dysfunction and greater prevalence of hypertension and obesity than the pre-TAVI group (table 1). Moreover, there was a trend towards less chronic pulmonary disease in the post-TAVI 2 group (table 1). The Logistic EuroSCORE I trended to decrease in the post-TAVI group 2 (table 1). The aortic valve area was larger in the 2 post-TAVI groups, compared with the pre-TAVI group (table 1). 
Concerning peri-operative data, there were significantly more urgent surgeries and lower decrease of the cardiopulmonary bypass and cross-clamp time in the post-TAVI 1 group (table 2). They were similar between the pre-TAVI group and the post-TAVI 2 group (table 2). The operative mortality was comparable (5.2\% in the pre-TAVI group, $6.9 \%$ in the post-TAVI 1 group, $4.3 \%$ in the post-TAVI 2 group). Concerning the incidence of early postoperative complications, there were statistically more cases of renal failure in the postTAVI 1 group.

\section{Discussion}

This single center study conducted within a tertiary heart valve clinic showed that, despite the availability of TAVI, the total number of SAVR cases continued to increase. While there were no significant changes in preoperative characteristics during the first 3 years after the availability of TAVI, we observed a decrease in the Logistic EuroSCORE I over the following 3 years. Nonetheless, the statistical significance was not reached. By the way, the operative mortality of octogenarians who underwent SAVR remained globally stable over time. There were no relevant differences in terms of peri-operative data and incidence of postoperative complications.

One previous single center study with similar design was performed in New Zealand ${ }^{20}$, with a smaller number of patients (35 patients in the pre-TAVI group and 33 patients in the post-TAVI group). Opposed to our results, octogenarian patients undergoing SAVR in such study were older, had lower left ventricular ejection fraction and higher EuroSCORE II in the post-TAVI era. However, this investigation was significantly limited by a very little sample size and the absence of mortality cases in either group.

We observed that the number of octogenarian patients undergoing surgery increased slightly in our institution over the study time frame, which is consistent with previous reports 
${ }^{10,21}$. Several factors may explain this finding. First, the absolute number of patients with symptomatic severe AS continues to increase in an aging population. Second, the possibility of a less invasive treatment with TAVI leads to an increased number of patients referred to tertiary centers for investigations. A significant percentage of these patients (about 10\%) will eventually benefit from SAVR after heart team discussion ${ }^{22}$. Finally, recent large studies including SAVR patients with high operative-risk showed good results with an operative mortality of $6.5 \%$ in the PARTNER Trial ${ }^{8}, 4.5 \%$ in the CoreValve US Pivotal trial ${ }^{23}$ and $7.0 \%$ in an octogenarian high operative-risk Italian population ${ }^{24}$. This supports an aggressive strategy in elderly patients.

Concerning the preoperative risk profile, patients undergoing SAVR appeared to be less severe in more recent periods. This is confirmed by a slight decrease of the Logistic EuroSCORE I in the post-TAVI 2 group of our study. Such features have been described here for the first time. This is probably the expression of referral of higher-risk surgical cases. This reasonably leads to better case mix selection for SAVR and eventually reduction of observed operative mortality.

In our study, the operative mortality was comparable, before TAVI 5.2\% (2006-2008), after TAVI 6.9\% (2009-2011) and 4.3\% (2012-2014). A slight difference was observed for the post-TAVI 1 group and could be explained by significantly higher proportion of urgent surgeries. These operative mortality rates are consistent with those of recent studies which range from $3.4 \%$ to $7.0 \%{ }^{8-10,13,21,23-26}$. Nevertheless, specific data about isolated SAVR in patients aged more than 80 years are scarce. Most studies are heterogeneous and extracted from databases not dedicated to precisely describe this population.

This retrospective analysis reported prospectively gathered information from a single tertiary-care referral center experience. It is thus limited in size, concerned a selected 
population and may not be generalizable. Nevertheless, it remains to the best of our knowledge the largest study on this subject to date. Retrospective observational studies like ours are inherently vulnerable to selection bias and unidentified confounding. However, all the data were collected prospectively and there was no missing data at the exclusion of the own limitations of the database.

\section{Disclosure of interest}

The authors have no conflicts of interest to disclose.

\section{Sources of Funding: None}


1. lung B, Baron G, Butchart EG, Delahaye F, Gohlke-Bärwolf C, Levang OW, Tornos P, Vanoverschelde J-L, Vermeer F, Boersma E, Ravaud P, Vahanian A. A prospective survey of patients with valvular heart disease in Europe: The Euro Heart Survey on Valvular Heart Disease. Eur Heart J 2003;24:12311243.

2. Eveborn GW, Schirmer H, Heggelund G, Lunde P, Rasmussen K. The evolving epidemiology of valvular aortic stenosis. the Tromsø study. Heart Br Card Soc 2013;99:396-400.

3. Lindroos M, Kupari M, Heikkilä J, Tilvis R. Prevalence of aortic valve abnormalities in the elderly: an echocardiographic study of a random population sample. J Am Coll Cardiol 1993;21:1220-1225.

4. Nkomo VT, Gardin JM, Skelton TN, Gottdiener JS, Scott CG, Enriquez-Sarano M. Burden of valvular heart diseases: a population-based study. Lancet 2006;368:1005-1011.

5. Otto CM, Prendergast B. Aortic-valve stenosis--from patients at risk to severe valve obstruction. $N$ Engl J Med 2014;371:744-756.

6. Stewart BF, Siscovick D, Lind BK, Gardin JM, Gottdiener JS, Smith VE, Kitzman DW, Otto CM. Clinical factors associated with calcific aortic valve disease. Cardiovascular Health Study. J Am Coll Cardiol 1997;29:630-634.

7. Carabello BA, Paulus WJ. Aortic stenosis. Lancet 2009;373:956-966.

8. Smith CR, Leon MB, Mack MJ, Miller DC, Moses JW, Svensson LG, Tuzcu EM, Webb JG, Fontana GP, Makkar RR, Williams M, Dewey T, Kapadia S, Babaliaros V, Thourani VH, Corso P, Pichard AD, Bavaria JE, Herrmann HC, Akin JJ, Anderson WN, Wang D, Pocock SJ, PARTNER Trial Investigators. Transcatheter versus surgical aortic-valve replacement in high-risk patients. $N$ Engl $J$ Med 2011;364:2187-2198.

9. Langanay T, Flécher E, Fouquet O, Ruggieri VG, La Tour B De, Félix C, Lelong B, Verhoye J-P, Corbineau H, Leguerrier A. Aortic valve replacement in the elderly: the real life. Ann Thorac Surg 2012;93:70-77. 
10. Barreto-Filho JA, Wang Y, Dodson JA, Desai MM, Sugeng L, Geirsson A, Krumholz HM. Trends in aortic valve replacement for elderly patients in the United States, 1999-2011. JAMA 2013;310:2078-2085.

11. Martínez-Sellés M, Gómez Doblas JJ, Carro Hevia A, García de la Villa B, Ferreira-González I, Alonso Tello A, Andión Ogando R, Ripoll Vera T, Arribas Jiménez A, Carrillo P, Rodríguez Pascual C, Casares i Romeva M, Borras X, Cornide L, López-Palop R, PEGASO Registry Group. Prospective registry of symptomatic severe aortic stenosis in octogenarians: a need for intervention. J Intern Med 2014;275:608-620.

12. Walther T, Blumenstein J, Linden A van, Kempfert J. Contemporary management of aortic stenosis: surgical aortic valve replacement remains the gold standard. Heart Br Card Soc 2012;98 Suppl 4:iv23-29.

13. Vasques F, Messori A, Lucenteforte E, Biancari F. Immediate and late outcome of patients aged 80 years and older undergoing isolated aortic valve replacement: a systematic review and metaanalysis of 48 studies. Am Heart $J$ 2012;163:477-485.

14. Cribier A, Eltchaninoff H, Bash A, Borenstein N, Tron C, Bauer F, Derumeaux G, Anselme F, Laborde F, Leon MB. Percutaneous transcatheter implantation of an aortic valve prosthesis for calcific aortic stenosis: first human case description. Circulation 2002;106:3006-3008.

15. Joint Task Force on the Management of Valvular Heart Disease of the European Society of Cardiology (ESC), European Association for Cardio-Thoracic Surgery (EACTS), Vahanian A, Alfieri O, Andreotti F, Antunes MJ, Barón-Esquivias G, Baumgartner H, Borger MA, Carrel TP, Bonis M De, Evangelista A, Falk V, Iung B, Lancellotti P, Pierard L, Price S, Schäfers H-J, Schuler G, Stepinska J, Swedberg K, Takkenberg J, Oppell UO Von, Windecker S, Zamorano JL, Zembala M. Guidelines on the management of valvular heart disease (version 2012). Eur Heart J 2012;33:24512496.

16. Nishimura RA, Otto CM, Bonow RO, Carabello BA, Erwin JP, Guyton RA, O’Gara PT, Ruiz CE, 
Skubas NJ, Sorajja P, Sundt TM, Thomas JD, ACC/AHA Task Force Members. 2014 AHA/ACC

Guideline for the Management of Patients With Valvular Heart Disease: executive summary: a report of the American College of Cardiology/American Heart Association Task Force on Practice Guidelines. Circulation 2014;129:2440-2492.

17. Leon MB, Smith CR, Mack M, Miller DC, Moses JW, Svensson LG, Tuzcu EM, Webb JG, Fontana GP, Makkar RR, Brown DL, Block PC, Guyton RA, Pichard AD, Bavaria JE, Herrmann HC, Douglas PS, Petersen JL, Akin JJ, Anderson WN, Wang D, Pocock S, PARTNER Trial Investigators. Transcatheter aortic-valve implantation for aortic stenosis in patients who cannot undergo surgery. $N$ Engl J Med 2010;363:1597-1607.

18. Lancellotti P, Rosenhek R, Pibarot P, Iung B, Otto CM, Tornos P, Donal E, Prendergast B, Magne J, Canna G La, Piérard LA, Maurer G. ESC Working Group on Valvular Heart Disease position paper-heart valve clinics: organization, structure, and experiences. Eur Heart J 2013;34:1597-1606.

19. Roques F, Michel P, Goldstone AR, Nashef SAM. The logistic EuroSCORE. Eur Heart J $2003 ; 24: 881-882$.

20. Wang TKM, Sathananthan J, Ramanathan T, Webster M, Ruygrok P. Isolated aortic valve replacement in octogenarians before and after the introduction of trans-catheter aortic valve implantation. Heart Lung Circ 2014;23:249-255.

21. Brown JM, O’Brien SM, Wu C, Sikora JAH, Griffith BP, Gammie JS. Isolated aortic valve replacement in North America comprising 108,687 patients in 10 years: changes in risks, valve types, and outcomes in the Society of Thoracic Surgeons National Database. J Thorac Cardiovasc Surg 2009;137:82-90.

22. Auffret V, Boulmier D, Oger E, Bedossa M, Donal E, Laurent M, Sost G, Beneux X, Harmouche M, Verhoye J-P, Le Breton H. Predictors of 6-month poor clinical outcomes after transcatheter aortic valve implantation. Arch Cardiovasc Dis 2014;107:10-20. 
23. Adams DH, Popma JJ, Reardon MJ, Yakubov SJ, Coselli JS, Deeb GM, Gleason TG, Buchbinder M, Hermiller J, Kleiman NS, Chetcuti S, Heiser J, Merhi W, Zorn G, Tadros P, Robinson N, Petrossian G, Hughes GC, Harrison JK, Conte J, Maini B, Mumtaz M, Chenoweth S, Oh JK, U.S. CoreValve Clinical Investigators. Transcatheter aortic-valve replacement with a self-expanding prosthesis. N Engl J Med 2014;370:1790-1798.

24. Eusanio M Di, Fortuna D, Palma R De, Dell'Amore A, Lamarra M, Contini GA, Gherli T, Gabbieri D, Ghidoni I, Cristell D, Zussa C, Pigini F, Pugliese P, Pacini D, Bartolomeo R Di. Aortic valve replacement: Results and predictors of mortality from a contemporary series of 2256 patients. $J$ Thorac Cardiovasc Surg 2011;141:940-947.

25. Eusanio M Di, Fortuna D, Cristell D, Pugliese P, Nicolini F, Pacini D, Gabbieri D, Lamarra M, RERIC (Emilia Romagna Cardiac Surgery Registry) Investigators. Contemporary outcomes of conventional aortic valve replacement in 638 octogenarians: insights from an Italian Regional Cardiac Surgery Registry (RERIC). Eur J Cardio-Thorac Surg Off J Eur Assoc Cardio-Thorac Surg 2012;41:1247-1252.

26. Saxena A, Poh C-L, Dinh DT, Reid CM, Smith JA, Shardey GC, Newcomb AE. Early and late outcomes after isolated aortic valve replacement in octogenarians: an Australasian Society of Cardiac and Thoracic Surgeons Cardiac Surgery Database Study. Eur J Cardio-Thorac Surg Off J Eur Assoc Cardio-Thorac Surg 2012;41:63-68. 


\section{Figure legends}

Figure 1. Number of octogenarian patients undergoing surgical aortic valve remplacement. 
Table 1. Preoperative characteristics

\begin{tabular}{|c|c|c|c|c|c|}
\hline Variables & $\begin{array}{l}\text { Pre-TAVI } \\
(\mathrm{n}=229)\end{array}$ & $\begin{array}{l}\text { Post-TAVI } 1 \\
(\mathrm{n}=288)\end{array}$ & p Value $^{*}$ & $\begin{array}{l}\text { Post-TAVI } 2 \\
(\mathrm{n}=328)\end{array}$ & $\mathrm{p} \mathrm{Value}^{\dagger}$ \\
\hline Age (years) & $83.2 \pm 2.0$ & $83.5 \pm 2.1$ & 0.11 & $83.5 \pm 2.1$ & 0.09 \\
\hline Age $\geq 85$ years & $49(21 \%)$ & $76(26 \%)$ & 0.19 & $92(28 \%)$ & 0.08 \\
\hline Female & $123(54 \%)$ & $152(53 \%)$ & 0.83 & $149(45 \%)$ & 0.05 \\
\hline NYHA class & & & 0.37 & & 0.37 \\
\hline I or II & $133(58 \%)$ & $156(54 \%)$ & & $203(62 \%)$ & \\
\hline III or IV & $96(42 \%)$ & $132(46 \%)$ & & $125(38 \%)$ & \\
\hline $\begin{array}{l}\text { Logistic EuroSCORE I } \\
(\%)\end{array}$ & $\begin{array}{l}12.4 \pm 5.9 \\
(10.4 \%)\end{array}$ & $\begin{array}{l}12.7 \pm 6.2 \\
(10.7 \%)\end{array}$ & 0.68 & $\begin{array}{l}11.6 \pm 5.1 \\
(10.1 \%)\end{array}$ & 0.06 \\
\hline $\begin{array}{l}\text { History of congestive heart } \\
\text { failure }\end{array}$ & $56(25 \%)$ & $75(26 \%)$ & 0.68 & $37(11 \%)$ & $<0.001$ \\
\hline Atrial fibrillation & $34(15 \%)$ & $58(20 \%)$ & 0.15 & $59(18 \%)$ & 0.35 \\
\hline Permanent pacemaker & $16(7 \%)$ & $13(5 \%)$ & 0.22 & $17(5 \%)$ & 0.37 \\
\hline Coronary artery disease & $51(22 \%)$ & $56(19 \%)$ & 0.43 & $33(10 \%)$ & $<0.001$ \\
\hline Cerebrovascular disease & $12(5 \%)$ & $15(5 \%)$ & 0.99 & $16(5 \%)$ & 0.85 \\
\hline Peripheral vascular disease & $49(21 \%)$ & $67(23 \%)$ & 0.61 & $60(18 \%)$ & 0.36 \\
\hline Chronic renal failure & $11(5 \%)$ & $20(7 \%)$ & 0.31 & $24(7 \%)$ & 0.23 \\
\hline $\begin{array}{l}\text { Chronic pulmonary } \\
\text { disease }\end{array}$ & $28(12 \%)$ & $28(10 \%)$ & 0.36 & $25(8 \%)$ & 0.07 \\
\hline Previous cardiac surgery & $7(3 \%)$ & $2(1 \%)$ & 0.08 & $6(2 \%)$ & 0.35 \\
\hline Hypertension & $135(59 \%)$ & $189(66 \%)$ & 0.12 & $227(69 \%)$ & 0.01 \\
\hline Diabetes mellitus & $19(8 \%)$ & $20(7 \%)$ & 0.56 & $27(8 \%)$ & 0.98 \\
\hline Obesity & $40(18 \%)$ & $70(24 \%)$ & 0.06 & $80(24 \%)$ & 0.05 \\
\hline LVEF (\%) & $60 \pm 12$ & $60 \pm 11$ & 0.92 & $61 \pm 10$ & 0.32 \\
\hline LVEF $<50 \%$ & $36(17 \%)$ & $43(16 \%)$ & 0.81 & $33(10 \%)$ & 0.02 \\
\hline $\begin{array}{l}\text { Mean aortic valve gradient } \\
(\mathrm{mmHg})\end{array}$ & $51 \pm 15$ & $51 \pm 17$ & 0.70 & $52 \pm 15$ & 0.40 \\
\hline Aortic valve area $\left(\mathrm{cm}^{2}\right)$ & $0.6 \pm 0.1$ & $0.7 \pm 0.2$ & 0.007 & $0.7 \pm 0.2$ & $<0.001$ \\
\hline
\end{tabular}

LVEF = left ventricular ejection fraction; NYHA = New York Heart Association; TAVI = transcatheter aortic valve implantation

* $p$ Value between pre-TAVI and post-TAVI 1

${ }^{\mathrm{p}} \mathrm{p}$ Value between pre-TAVI and post-TAVI 2

$\$$ Obesity defined as a body mass index $>30 \mathrm{~kg} / \mathrm{m}^{2}$ 
Table 2. Peri-operative data

\begin{tabular}{|c|c|c|c|c|c|}
\hline Variables & $\begin{array}{l}\text { Pre-TAVI } \\
(\mathrm{n}=229)\end{array}$ & $\begin{array}{l}\text { Post-TAVI } 1 \\
(\mathrm{n}=288)\end{array}$ & p Value* & $\begin{array}{l}\text { Post-TAVI } 2 \\
(\mathrm{n}=328)\end{array}$ & p Value ${ }^{\dagger}$ \\
\hline Operation status & & & 0.03 & & 0.32 \\
\hline Elective & $227(99 \%)$ & $277(96 \%)$ & & $321(98 \%)$ & \\
\hline Urgent & $2(1 \%)$ & $11(4 \%)$ & & $7(2 \%)$ & \\
\hline $\begin{array}{l}\text { Cardiopulmonary } \\
\text { bypass time (min) }\end{array}$ & $57 \pm 19$ & $54 \pm 14$ & 0.01 & $57 \pm 19$ & 0.98 \\
\hline $\begin{array}{l}\text { Cross-clamp time } \\
(\mathrm{min})\end{array}$ & $44 \pm 15$ & $42 \pm 11$ & 0.02 & $45 \pm 16$ & 0.45 \\
\hline Bioprosthetic valves & $229(100 \%)$ & $288(100 \%)$ & 1.00 & $328(100 \%)$ & 1.00 \\
\hline
\end{tabular}

TAVI $=$ transcatheter aortic valve implantation

* $p$ Value between pre-TAVI and post-TAVI 1

${ }^{\dagger} \mathrm{p}$ Value between pre-TAVI and post-TAVI 2 
Table 3. Operative mortality and postoperative complications

\begin{tabular}{llllll}
\hline Variables & $\begin{array}{l}\text { Pre-TAVI } \\
(\mathrm{n}=229)\end{array}$ & $\begin{array}{l}\text { Post-TAVI } 1 \\
(\mathrm{n}=288)\end{array}$ & $\mathrm{p} \mathrm{Value} *$ & $\begin{array}{l}\text { Post-TAVI } 2 \\
(\mathrm{n}=328)\end{array}$ & $\mathrm{p} \mathrm{Value}$ \\
\hline $\begin{array}{l}\text { Operative mortality } \\
\text { (30-day) }\end{array}$ & $15(5.2 \%)$ & $20(6.9 \%)$ & 0.42 & $14(4.3 \%)$ & 0.59 \\
$\begin{array}{l}\text { Reoperation for } \\
\text { bleeding }\end{array}$ & $5(2 \%)$ & $6(2 \%)$ & 1.00 & $10(3 \%)$ & 0.53 \\
$\begin{array}{l}\text { Tamponade } \\
\begin{array}{l}\text { Ventilatory support } \\
>48 \mathrm{~h}\end{array}\end{array}$ & $7(3 \%)$ & $9(3 \%)$ & 0.96 & $16(5 \%)$ & 0.29 \\
$\begin{array}{l}\text { Renal failure } \\
\text { Stroke }\end{array}$ & $13(6 \%)$ & $36(13 \%)$ & 0.01 & $19(6 \%)$ & 0.95 \\
Blood transfusion & $2(1 \%)$ & $5(2 \%)$ & 0.47 & $1(1 \%)$ & 0.57 \\
Atrial fibrillation & $112(51 \%)$ & $136(48 \%)$ & 0.54 & $163(50 \%)$ & 0.86 \\
Pacemaker implantation & $5(2 \%)$ & $12(4 \%)$ & 0.21 & $5(2 \%)$ & 0.75
\end{tabular}

TAVI $=$ transcatheter aortic valve implantation

* $p$ Value between pre-TAVI and post-TAVI 1

${ }^{\dagger} \mathrm{p}$ Value between pre-TAVI and post-TAVI 2 


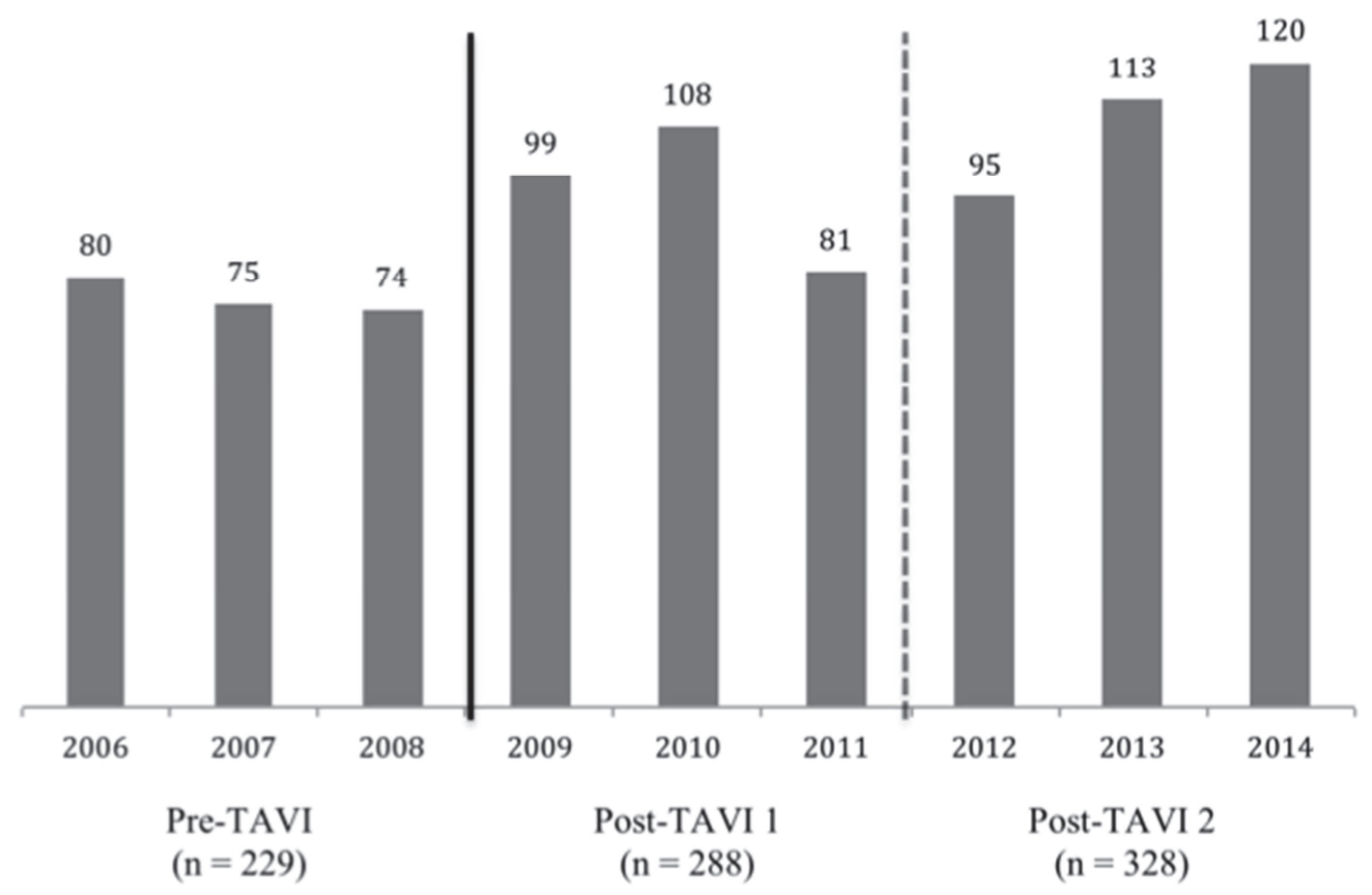

